Historic, archived document

Do not assume content reflects current scientific knowledge, policies, or practices. 



\section{FLOWER AND GARDEN SEEDS}

Send us this list at once whether you order seeds at once or notTen names of persons interested in seeds, etc., and we will send you, Free, 25c worth of garden or flower seeds, selected from our 1925 Catalogue-you do the selecting.

This offer expires Feb. 25, 1925. Send us this list at once.

Your own name and address

Name

\section{Address}

\section{ZACK




\section{Gladioli Bulbs}

MRS. FRANK PENDLETON

$8 c$ each ; 75c per dozen

AMERICA

$5 \mathrm{c}$ “ $50 \mathrm{c}$

HALLEY

$8 \mathrm{c}$ “ $75 \mathrm{c}$

MRS. FRANCIS KING

$5 \mathrm{c}$ “ $50 \mathrm{c}$

PANAMA

$8 c$

SCHWABEN

$8 c$ “ “75c '

NIAGARA

$8 \mathrm{c}$ “ $75 \mathrm{c}$

PEACE

$8 \mathrm{c}$

AUGUSTA

$5 \mathrm{c}$

CHICAGO WHITE

$8 \mathrm{c}$

WAR

$10 \mathrm{c}$

PRINCE OF WALES

$8 \mathrm{c}$

1.00

One each of the above 12 varieties $50 \mathrm{c}$

\section{Dahlias}

MIXED DAHLIAS _.......15c each ; 2 for $25 \mathrm{c} ; \$ 1.20$ per doz. postpaid ONE EACH of 12 different varieties

1.20

NAMED VARIETIES 20c each : 3 for $50 \mathrm{c} ; 1.75$

\section{Cannas}

CANNAS

15 e each ; $\$ 1.50$ per doz. postpaid Each bulb labelled.

\section{Pansy Plants}

(Steele's Giant Mixed)

Although the Pansy is a hardy perennial, it is usually treated as an Annual or a Biennial. The plants we have to offer are hardy and can be planted early. They will bloom from June until frozen down in the fall. Strong well rooted plants, ready to bloom, postpaid: $60 \mathrm{c}$ per dozen ; 50 for $\$ 2.00$.

\section{Zack Davis Seed Company}

DELAWARE, OHIO 